\title{
La teología poética de Pedro Casaldáliga (II)
}

\section{Víctor Codina \\ Centro de Investigación y Servicio Popular (C.I.S.E.P), \\ Oruro. Bolivia.}

\section{Símbolos teológicos}

El itinerario recorrido no agota el transfondo teológico de la poesía de Casaldáliga. Toda la dogmática y la espiritualidad se halla presente en sus versos, pero no de forma escolar sino simbólica. Recoger con cuidado estos símbolos, cotcjarlos, iluminarlos a través de la polisemia de significados, es tarea delicada, pero sugerente. Es difícil elegir entre varios símbolos el más repetido y primigenio. Es audacia desvelar el misterio de cada palabra, de cada frase, de cada verso. Sin embargo, la misma polivalencia de sentidos nos dice que nos hallamos ante un mundo rico, seguramente más vivo y menos sofisticado que muchas definiciones teológicas, que, al precisar, delimitan. Dejemos hablar al poeta, entremos en su mundo sin imponerle nuestros moldes. Solo así saldremos renovados. Porque Casaldáliga no expresa en versos las enseñanzas teológicas de la escuela, sino que traduce en forma poética la experiencia espiritual que está en la base de toda teología.

\subsection{El claroscuro de la fe}

Ante la pregunta de Teófilo Cabestrero sobre su fe, Casaldáliga responde sin relicencias:

Me preguntas por mi fe.

¿Te respondo llanarnente?

Creo en Dios

Creo en el hombre

Creo en el Señor Jesús.

Creo en la pobre María y en toda la Iglesia pobre.

Creo en la tierra de todos como la madre primera. 
Creo en los nuevos lugares,

con lugar para reír al aire libre (otra vez naturaleza);

con lugar para sentirse compantí (otra vez humanidad);

con lugar para vivir la vida eterna (ya en el tiempo)

con lugar para esperar la gloria eterna 99

Pero esła fe está rodeada de misterio:

Os quedaréis sin la vida

Si le quitáis el misterio.

Hay que salvar el aroma

de la madera cortada...

Servir bajo el día a día.

Creer contra la evidencia

Decir siempre una palabra

última de lucha,

para caer luego de rodillas

en silencio... 100

Este caer de rodillas, que recuerda la kniende Theologie que defendía Karl Rahner, se enlaza temáticamente con otras palabras de Rahner que le impresionan al poeta:

- ¿qué estás haciendo ahora?

le preguntaba el papa (¿inquisidor? ¿benévolo?)

Respondía el teólogo (¿evasivo? ¿maestro?)

Me preparo a vivir el gran Encuentro. ${ }^{101}$

Y más adelante, como asumiendo la lección de Rahner, continúa:

Rahner lo ha dicho. Y ya no hay más lecciones:

- la cima de la vida está aún por llegar.

es el abismo

del Misterio de Dios

donde nos despeñamos

libres por lin

muriendo...

Capitulo ante Ti, oh Dios, Innominado, ¡Mayor siempre!

"solitarios extraños" vamos hacia tu encuentro,

¡Sentido de la sed de todos los sentidos! 102

La fe es algo más que recilar una fórmula, definir conceptos, defender una bandera. Es sentido, es silencio, oración, misterio, gran encuentro, claroscuro:

Claroscuro del sentido,

claroscuro de la fe.

Creo la luz que se ve, veo el misterio escondido.

Claroscuro voy perdido 


\author{
de belleza y de verdad. \\ Sombras, decidme. Callad \\ luces sabidas. Creer \\ es la manera de ver \\ total la realidad. 103
}

Creer es buscar al Dios oculto, ${ }^{104}$ es hallar el manantial en la gruta, 105 es respirar a Dios y dejarse acariciar por su brisa:

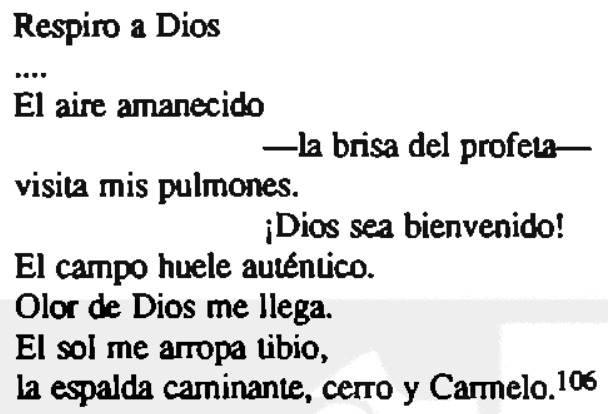

Pero creer supone, también esclarecer muchos equívocos:

Donde ứ dices ley,

Yo digo Dios.

Donde tú dices paz, justicia, amor, ¡yo digo Dios!

Donde tú dices Dios, ¡Yo digo libernad, justicia, amor! 107

Para Casaldáliga la fe tiene que ver con el misterio de Dios, con la vida y con la mucrte de los hombres. Sin justicia, sin amor, sin libertad, no hay fe.

\title{
3.2. Trinidad venida a menos
}

A veces se escuchan acusaciones a teólogos latinoamericanos por no haber abordado el tema trinitario. Casaldáliga no elabora un tratado de trinidad, pero habla de ella y la invoca. Acaba su bendición a Leonardo Boff, poniendo en boca de San Francisco estas palabras:

Para Gloria del Padre que nos crcó libres, en la Pascua del Hijo que con su sangre nos liberó de todo cautiverio y en la consolación del Espírilu Santo que es el sello vivo de nuesira libertad

Amén iAlcluya! 108

Es una trinidad que genera liberad y nos libera de todo cautivcrio. Pero seguramente donde explana con más amplitud este tema es en el poema que dedica 
a la pintura mural de Maximino Cerezo, en Ribeiră Bonito, para conmemorar los diez aftos del martirio del P. Joao Bosco Penido Burnier. En el cuadro aparece el Cristo resucitado, con sus llagas, que encabeza la caminhada de los mártires de Amércia Latina Las manos del Padre acogen a wodos los mártires y defienden a los que Lodavía sufren tortura y prisión, mientras a lo lejos, el Esplritu en forma de garza blanca acompanta al pueblo en su caminar. Casaldáliga expresa así esta visión trinitaria:

Tus manos sobre los Pobres, por Tí llegados a Dios

$y$ acogidos en familia

de igualdad comunitaria.

Tus manos en las del Padre, corriente de un mismo Espíritu,

Tus manos en cruz tendidas

hacia las manos del Mundo, orillas del Tiempo Nuevo, Camino, Verdad y Vida.

Trinidad venida a menos

para hacemos todo a lodos, Manos/Casa,

Llagas/Pascua,

¡Uno y nuestro!

¡Trinidad que nos arrastras

lucha adentro, Pueblo adentro,

con el Hijo,

pobre Hermano

Lambiên mucrio! 109

Es ésta una trinidad abierta al mundo, que arrastra a la lucha, que se entrega y nos hermana, una trinidad en la que Crislo nos lleva al Padre y nos da el Espíritu, una trinidad acogedora, Manos abiertas, llagadas, voladoras. Es una trinidad kenólica, venida a menos, acogedora de los pobres, desde el mismo Hijo, pobre $y$ muerto. Es una trinidad dinámica, en marcha con el pucblo. Esta visión no contradice las afirmaciones de la Iglesia sobre la trinidad, ni las patrísticas, ni las escolásticas, ni las modemas sobre la trinidad inmamente y económica. Pero lo expresa todo desde un simbolismo vivo y cercano al pueblo, al pueblo que sufre. Es una trinidad manirial, en pie de testimonio y en memoria subversiva. Es una trinidad, que, como autores orientales han recordado y tcólogos latinoamericanos han escrito recientemente, liene que ver con la socicdad y la justicia.

\subsection{Libertador total}

La cristología de Casaldáliga no es tcórica sino vital, no es apenas una cristología de nominativo, sino de vocativo, es una cristología de búsqueda, de 
memoria, de seguimiento, de esperanza en medio de la lucha, de pasión y de pascua. ${ }^{110}$

Comentando el canto "acuérdate de Jesucristo" afirma:

$\mathrm{Me}$ acuerdo muy bien de El.

A todas horas.

Me acuerdo de El, buscándolo

en loda cosa, en todos;

sintiéndome buscado

por sus ojos gloriosamente humanos:

sinuéndome seguido, reclamado, jwzgado,

por tantos ojos suyos, todavía terrenos. ${ }^{111}$

Es un Crisio que se desnuda de su gloria para entrar en este mundo:

Entra en picaso

por aquella kénosis

desnudamente,

de abismo en abismo,

hasta el foso fecundo de la muerte. ${ }^{112}$

Es un misterio paradójico. Casaldáliga expresa con gran plasticidad y belleza poética el misterio de la encarnación, dejando atrás el sabor escolástico de tantos tratados teológicos:

Sus manos y Sus pies de tierra llenos, rostro de carne y sol del Escondido. ¡versión de Dios en pequeffez humana! 113

Desde la aldea de indios Tapirapé la navidad tiene un sabor especial:

Una canoa pesca los peces de colores del ocaso

en la perfecta placidez del lago.

$Y$ en la arcilla cocida,

sobre la arena, pura

como polvo de estrellas,

Dios ha nacido indio...114

Y es que la navidad por ser un misterio no sólo de pobreza sino de los pobres, sólo se capta desde ellos:

Porque los pobres son la mayoría,

si faltan los pastores

Belén es una farsa. 115

Consiguientemente, la navidad es no sólo la hominización de Dios, sino su opción por los pobres. Casaldáliga lo ha expresado en un verso que ha escandalizado a muchos bienpensantes, a curias y a sinagogas:

En el vientre de Maria

Dios se hizo hombre, 


\section{Y en el taller de José}

Dios se hizo también clase 116

Belén y las bienaventuranzas son señales certeras de Jesús, su cruz es vivida desde las cruces de hoy, su muerte es como las de hoy, por orden del imperio, su sepulcro vacío anuncia la resurteción, también la del pueblo:

Su sepulcro vacío nuestros sepulcros llenos

de pueblo masacrado anuncian la Martana. 117

Pero es sobre todo el Cristo resucilado, el de Tiberiades, el que Casaldáliga canta con esperanzada fruición en inspirados versos:

Jesús de Nazareh, hijo y hermano, viviente en Dios y pan en nuestra mano, camino y compañero de jornada, Libertador total de nuestras vidas que vienes, junto al mar, con la alborada, las brasas y las llagas encendidas. 118

Este Cristo, que con sus manos llagadas, reparte pan y pescado junto a las brasas, a orillas del lago, es un Cristo joanneo, transfigurado por la luz de la pascua. Como veremos luego, este Jesús junto al lago marca también la eclesiología de Casaldáliga.Pero el fulgor de la resurreción no permite olvidar el escándalo de la vida del Jesús histórico, semejante al escándalo del pobre histórico de hoy:

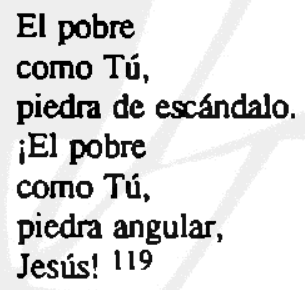

Así están puestos los fundamentos para una Iglesia de los pobres y para una mariología liberadora.

\subsection{Profetisa de la liberación}

Hay una clara presencia mariana en la obra poética de Casaldáliga, sin duda unida a su vocación cordimariana. Pero esla presencia es muy peculiar. Siempre matema, pero cada vez más identificada con el pueblo y sus sufrimientos. Si, tal vez, sus primeras poesías marianas son más abstractas y estéticistas, a medida que avanza el tiempo crece la concreción y María adquiere rostros más concretos, po-pulares, humanos. Pero siempre María queda desmitificada. No es la reina llena de joyas, sino una mujer de cada día, que cuece el pan, lava la ropa, ordefla cabritas, hila en su huso, ayuda a sus vecinas, cuida sus flores, peregrina al templo. En este marco anota el poeta: 
Y el Verbo se hace Hombre, día y noche delante de us ojos al filo de tus manos, detrás de us silencio. ${ }^{120}$

María es una mujer del campo 121 comadre de suburbio, 122 que ha instalado a Dios en el suburbio humano, aldeana que se perdería en nuestras grandes ciudades, 123 es Santa María, sin más tútulos 124 De su estancia en Africa, Casaldáliga guarda un poema exuberante y exótico sobre la Virgen negra:

Rebaños de elefantes se acercan a tus pies, con sus antorchas de maril en alto,

y el ébano levanta sus columnas para acoger tu came transparente. (125)

Pero, lentamente, Maria adquiere un rostro indio y se vuelve protectora de los indios:

Morena de Guadalupe,

Maria del Tepeyac:

congrega a todos los indios

en la estrella de tu mirada;

convoca a los pueblos de América

que quieren resucitar. 126

Oras veces el poeta que vive fuertemente la soledad y la proximidad de la muerte, invoca a María como señora de la soledad:

Sola contra la noche del Misterio, por las arenas de la Fe abrasada. 127

Y como Seffora de la Muerte:

Morir bajo uu nombre es encontrar de pronto

detrás de las cortinas, la Fiesta preparada.. 28

Todo este proceso se recapitula en su poema Maria de nuestra liberación:

María de Nazaret, esposa prematura de José cl carpintero

-aldciana de una colonia siempre sospechosa-

campesina anónima de un valle del Pirineo,

rezadora sobresal tada de la Lituania prohibida,

indiecita masacrada de El Quiché,

favelada de Río de Janeiro,

negra segregada en el Apartheid,

harijan de la India,

gitanilla del mundo;

obrera sin cualificación, madre soltera, monjila de clausura;

niña, novia, madre, viuda, mujer.

Cantadora de la Gracia que se ofrece a los pequeños, porque sólo los pequeños saben acogerla;

profetisa de la liberación que solamente los pobres conquistan, 
porque sólo los pobres pueden ser libres:

queremos creer como tú,

queremos orar contigo,

queremos cantar us mismo Magnificat. 129

La vida de esta mujer creyente y fiel, dispuesta a "cantar, agradecida, en la montaña, para todos los vientos de la Historia," el gozo de los pobres libertados, 130 es María Pentecostés:

cuando la Iglesia aún era

pobre y libre

como el viento del Espíritu.

María Pentecostés

cuando el fuego del Espíritu

era la ley de la Iglesia. ${ }^{131}$

Maria, pobre y libre, con la libertad del Espiritu es imagen y modelo de la Iglesia pobre y de los pobres,

\subsection{Mar de Tiberíades}

¿Cuál es la imagen poética y simbólica predominante en la eclesiología del obispo, que tan crítico es frente a la curia, la sinagoga, el sinedrio y el inviemo eclesial?

Creemos que su eclesiologia simbólica gira en tomo a la pericopa de Juan 21, verdadera parábola de la Iglesia del futuro, misterio de una pesca milagrosa, de la presencia del Resucitado desde la orilla de la escatología, de una comida fraternal junto a las brasas, profesión petrina de amor y encargo de pestoreo, profecía del martirio y tensión escatológica hasta que el Seffor vuelva. $Y$ todo ello bajo la brisa matinal y el Viento del Espirf́n. Estas inágenes marinas son, por lo demás, muy frecuentes en la eclesiología patrística.

En los poemas de Casaldáliga se entremezclan las imágenes, los símbolos se superponen. Tiberíades es el Araguaia, el mar se abre al océano ecuménico del reino, reino adentro es mar adentro, Tiberiades se une a Belén y a las bienaventuranzas, Pedro es Juan Pablo II y el propio obispo de Sao Félix, el mar es don y quehacer... La imagen que surge de Iglesia es la de una Iglesia vivificada por el Viento del Espíritu y que vuelve a sus raf́ces evangélicas:

Podría ser el mar Tiberlades, orilla de sus pies.

Simón llegaba adusto, y echaba la mirada como una inquiela red:

-Maestro ¿Tú qué dices?

-Pedro, vamos a ver...

-El Reino como sabes, pasa bajo las aguas igual que un pez.

Podria ser el mar de Tiberfades, 
si el Araguaia es. 132

$Y$ en un poema titulado "Pedro, ¿me amas?", Tiberiades adquiere un tono personal, el obispo de Sao Félix es el viejo Simón:

Todas las noches

todos los días

para pescar,

y Tú en la playa,

resucitado

frente a mi afán.

Yo te sabla

sin preguntarte

junto a las brasas

vivo en el Pan. ${ }^{133}$

En el "Salmo entre esperanzado y melancólico de un obispo tachado de comunista." sueña con el Vaticano II y el Vaticano II, en Jerusalén II, Belén, Belén I, en que todos seamos:

más libres, más humanos, más hermanos, más nuevos;

los fieles, los pequefios sobre todo,

incluso los obispos

-otra vez pescadores de horizontes, otra vez curtidores de Evangelio,

otra vez degollados, las cabezas sin mitra, en las plazas mayores del

Imperio para dar testimonio- 134

$\mathrm{Y}$ pone en labios de San Francisco estas sofiadoras palabras para Fray Leonardo Boff:

El viento libre del mar de Tiberíades

y las aves evangelizadoras del monte de las Bienaventuranzas

invadirán, para alegria de los Pobres todo el recinto...

recino de la Iglesia de nuestro Salvador Jesús. ${ }^{135}$

A Pedro se le pide, no sólo que deje la curia y vaya al huerto de las bananeras, sino también:

Diles, dínos a lodos,

que siguen en vigencia indeclinable

la gruta de Belén,

las Bienaventuranzas

Y el Juicio del amor dado en comida.

¡No nos conturbes más!

Como Lo amas,

ámanos,

simplemente,

Danos, con tus sonrisas, con tus lágrimas nuevas,

de igual a igual, hermano. 
el pez de la Alegría,

el pan de la Palabra,

las rosas del rescoldo...

...la claridad del horizonte libre,

el Mar de Galilea ecuménicamente abierto al Mundo. 136

$Y$ en otro poema le dice a Juan Pablo II:

Alienta en tus hermanos

la libertad del Viento,

pescador.

Confirma nuestra fe

con tu amor.

Danos la audiencia de la profecía

y la encíclica del silbo del pastor.

El uribunal de los pobres

juzga nuestra misión.

La buena Nueva,

hoy como siempre,

es de Liberación. ${ }^{137}$

La eclesiología de Casaldáliga no es sistemática, sino profética, no se detiene a enumerar cánones, sino que descubre lo esencial: la vuelta al mar de Tiberfades, necesidad urgente de un tiempo en que la Iglesia parece entrar en invierno y el frío llena de tristeza al pueblo sobre el que Dios ha derramado su Espiritu. Es propio del profeta descubrir, en medio de la hojarasca, lo esencial, volver a las raices, hacer que los medios no oculten al fin, volver a situar a la Iglesia frente al juicio de los pobres, frente al reino. Casaldáliga lo logra con imágenes evangélicas del lago y la pesca.

\subsection{Octavo sacramento}

En vano buscaremos en nuestro autor una sacramentología sistemálica, pero como siempre, pone el dedo en la llaga sobre el sentido de los sacramentos y exclama proféticamente:

\section{El Esplritu \\ ha decidido \\ administrar \\ el octavo sacramento: \\ ¡la voz del Pueblo! 138}

No pretende negar ni cuestionar los siete sacramentos de la Iglesia, sino más bien enlazarlos con el sacramento de la historia, con el pobre como sacramento de Jesucristo (Mt 25), desea unir el sacramento del altar con el sacramento del hermano, como pedian los padres de la Iglesia. En el clamor del pobre, en su grito, en su voz muchas veces aplastada, clama el Señor y su Espíritu, y sólo escuchándola, la Iglesia podrá ser fiel a su misión. 
En este mismo sentido, en su poema dedicado a Gustavo Gutiérrez pregunta:

¿Qué darésis por sacramento

si no os dais en lo que deis?139

Más concretamente, sobre la eucaristía tiene Casaldáliga ardientes versos, siempre uniendo el pan y el vino con la pasión y la sangre del pueblo, con su hambre y con su trabajo. Escribiendo sobre el pan de cada día dice:

Jesís es el pan vivo.

El universo es nuestra mesa, hermanos.

Las masas tienen hambre,

y este Pan

$$
\text { es su Carne, }
$$

destrozada en la lucha,

vencedora en la muerte.

Somos familia en la fracción del pan.

Sólo al partir el pan

podrán reconocernos.

Searnos pan, hermanos.

Danos, oh Padre, el pan de cada día:

el arroz o el maiz o la cortilla,

el pan del Tercer Mundo! 140

Y en un poema sobre el culto vivo, que algunos, con evidente miopia, han llegado a interpretar como negación del sacerdocio ministerial, cuando en realidad habla de la eucaristía desde una perspectiva litúrgica, cósmica y patrística, escribe:

Que el pueblo tenga en sus manos

el pan de la Eucaristia, puesto que el pueblo hace el pan.

La tierra y su esposo, el Hombre, produzcan la Eucaristia, culto vivo al Dios vivo. 141

Decididamente las reglas para una hermencutica poética y simbológica no son las mismas que las de la hermanéutica simlogicosistemática. La Schuliheologie y la Denzingertheologie, para usar términos rahnerianos, difícilmente pucden comprender a los poetas y menos a los profetas...El horizonte úlumo de la sacrameniología de Casaldáliga, como lambién de su eclesiología, es cl reino...

\subsection{El monte Carmelo}

Si hay un terreno en el que Casaldáliga se mueve con soltura es el de la espiritualidad. Amigo de la soledad y el silencio, contemplativo por naturaleza, místico por gracia, vive la savia de la espiritualidad más tradicional, pero desde un horizonte nuevo. Así, contemplando el ciprés de Itaici, valora su ascetismo 
solitario, su anhelo de oración, su verde pertinacia de cirio pascual, que lo asemejan al ciprés del monasterio de Silos, cantado por Gerardo Diego, pero pronto advierte las diferencias:

Allá el mudo ciprés en su fervor

de Silos. ¿Todavia mudo? Aquí

aljaba de combates, el clamor

de este cirprés profeta de Itaici. ${ }^{142}$

La espiritualidad de Casaldáliga brota de una pasión por el reino:

Nunca te canses de hablar del Reino, nunca te canses de hacer el Reino, nunca te canses de discernir el Reino, nunca te canses de acoger el Reino, nunca te canses de esperar el Reino. ${ }^{143}$

$Y$ en otro lugar dice:

Somos en última instancia

el Reino que nos es dado

y que hacemos cada día

y hacia el que, anhelantes, vamos. ${ }^{144}$

Este reino vienen a contramano, ${ }^{145}$ es diferente, ${ }^{146}$ exige una opción:

No se puede servir a dos seffores:

al Pueblo y al Poder,

al Reino y al Sisterna,

al Dios de Jesuscrito y al Diablo del dinero. ${ }^{147}$

Llevar adelante este reino exige una acuitud de pobreza evangélica:

No tener nada.

No llevar nada

No poder nada.

No pedir nada.

Y de pasada,

no matar nada,

no callar nada.

Solamente el Evangelio como una faca afilada. ${ }^{148}$

Esta pobreza no es algo simplemente interior o estético, es una pobreza inseparable de los pobres reales y de su clamor. A Leonardo Boff, silenciado por Roma, le dice:

Comparte en profundidad el misterio de los Pobres

que no tienen voz ni en la Socicdad ni en la Iglesia.

...

Escucha, en mayor silencio,

el grito de los oprimidos que brota de este Continente de la muerte y la 


\section{esperanza}

y el canto nuevo que ya rompe de las aldeas indigenas,

de los campos y ciudades. 149

$Y$ un afio después, levantado su silencio, le añade:

- Hermano Leonardo,

té́logo confirmado de la Liberación

por la gracia del Padre y el apremio del Pueblo:

ahora que nuestros seflores

los maestros de Roma

te han devuelto la Palabra,

devuélvesela entera

a tu Seftor, el Pobre. 150

También el celibato adquiere una dimensión popular.

Vivo en soledad

pero engendro pueblo.

Y mi corazón

envejece nuevo.

...

Con todos los míos

yendo solo, voy.

$Y$ tengo por Patria

el rostro de Dios. 151

Pero quiźs es en sus Preguntas para subir y bajar el monie Carmelo, homenaje a G.Gutiérrez por su libro de espiritualidad Beber en su propio pozo. donde el autor expresa con mayor claridad este rumbo nuevo de la espiritualidad latinoamericana que él experimenta:

Por aquí ya no hay camino ¿Hasta dónde no lo habrá? ...

¿Por dónde iréis hasta el cielo si por la tierra no vais?

¿Para quien vais al Carmelo, si subís y no bajáis?

¿Sanarán vicjas heridas las alcuzas de la ley? ¿Son banderas o son vidas las batallas de este Rey? ¿Es la curia o es la calle donde grana la misión?

Si dejais que el viento calle ¿qué oiréis en la oración? 
Si no oís la voz del Viento ¿qué palabra levaréis?

Si cedéis ante el Imperio

la Esperanza y la Verdad ¿quién proclamará el misterio de la entera Libertad? Si el Seflor es Pan y Vino y el Camino por do andáis si al andar se hace camino ¿qué carninos esperáis? ${ }^{152}$

La imagen de Elías, el tesbita fugitivo de los que le persiguen y que busca a Dios en el Carmelo, se repile en sus poemas:

El sol me arropa, tibio, la espalda, caminante, cerro y Carmelo ...

Abro mi cruz, mis brazos, a todo lo que venga.

Sé que también me espera la jomada de Elías...

Pero ahora, hermanos, respiro a Dios, lo huclo a campo abierto. ${ }^{153}$

\subsection{La voz del viento}

Esta espiritualidad es, en última instancia, escuchar el viento, dejarse llevar por él, no ahogarlo. Para Casaldáliga el viento es el símbolo preferido para hablar del Espíritu. Es el viento de pentecostés, 154 el viento de Tiberíades, ${ }^{155}$ el viento que Juan Pablo debe alentar. ${ }^{156}$ Estc es cl viento que cl poela lamenta que haya sido amarrado en Puebla, 157 el viento que en su pocma sobre la trinidad sc presenta como alas-viento. ${ }^{158}$ Es el viento, suave a veces, impetuoso otras, que mueve la historia, el pueblo, la Iglesia.

A este viento dedica el poeta uno de sus libros, Fuego y ceniza al Viento:

Al viento de su Espíritu

que sopla donde quiere, libre y liberador, vencedor de la Ley, del Pecado y de la Muerte.

Al Viento de su Espíritu que se remansó en el corazón y en el vientre de una aldcana de Nazarel.

Al Viento de su Espíritu que se apoderó de Jesús para enviarlo a anunciar la Buena Nueva a los pobres y la liberación a los caulivos.

Al viento de su Espíritu 
que se llevó en Pentecostés

los prejuicios, los intereses y el miedo de los Apóstoles

y abrió de par en par las pueráas del cenáculo,

para que la comunidad de los seguidores de Jesús

fuera siempre abierta al Mundo

y libre en su palabra

$y$ coherente en su testimonio

e invencible en su esperanza.

Al viento de su Espíritu

que se lleva siempre

los nuevos miedos de la Iglesia

y abrasa en ella todo poder que no sea servicio fratemo

y la purifica con la pobreza y cl Martirio.

Al Viento de su Espíritu

que reduce a cenizas

la prepotencia, la hipocresía, y el lucro,

y alimenta las llamas de la Justicia y de la Liberación

y es el alma del Reino.

Para que seamos viento en el Viento, hermanos. 159

La espiritualidad que aparece en las obras poéticas de Casaldáliga no es simplemente esfuerzo y combate, es dejarse llevar por el Viento del Espírtu, captar la brisa que acaricó a Elías, 160 es dejarse purificar por el. El símbolo joanneo del vienio, que no se sabe de dónde viene ni a donde va, es asumido por el poeta del Brasil (Jn 3,7), para expresar la fucrza del Espínitu que rompe moldes y previsiones. La espiritualidad es pneumatología. Pero una pneumatologia que no sólo sube al monte Carmelo, sino que también baja a la calle, donde se escucha la voz del viento que habla a través de la voz de los sin-voz, que camina con el pucblo y no tiene más palabra que la misma voz del viento:

La muerte sobre el camino,

el Pueblo por compañia.

y el Viento por toda voz. ${ }^{161}$

Sólo el viento nos puede hacer descubrir los nuevos caminos del pueblo y alentar nuestra esperanza contra toda esperanza. Y es tan imprevisible y ligero como la garza blanca...

\subsection{Al calor de tu casa}

Una constante de la poesía de Casaldáliga es su continua alusión a la muerte, que le ronda, 162 le acuna como una madre, ${ }^{163}$ conslituye la hora de la verdad, ${ }^{164}$ su hora:

Mi vida

son

muchos dias. 
será

la hora. ${ }^{165}$

Siempre se encuentra entre el instante y la muerte, 166 camina hacia una muerte inevitablemente fatal, pero lambién pascual. ${ }^{167} \mathrm{La}$ teme, pero va a su encuentro:

Vendrá Saldrá de mí. La llevo denuro desde que soy. $Y$ voy hacia su encuentro con todo el peso de mis años vivos.

Pero vendrá... para pasar de largo.

$Y$ en la centella de su beso amargo

vendremos Dios y yo definitivos. ${ }^{68}$

Pero mientras, hay una tarea:

Hablemos de la tarea

de nuestra caducidad,

que es hacer que el Ticmpo sea,

todo él, Eternidad. ${ }^{169}$

Y después de la muerte, ¿qué?:

Al morir recibiremos

como sacramente último

el olvido de lo malo.

La Gloria será en gran parte

un recuerdo agradecido. 170

Y el juicio será un abrir el corazón:

Al final del camino me dirán:

— ¿Has vivido? ¿Has amado?

$Y$ yo sin decir nada, abriré el corazón lleno de nombres, ${ }^{171}$

Esta versión poética de Matco 25 se completa con otro gozoso descubrimiento:

Y llegaré de noche, con el gozoso espanto

de ver,

por fin,

que anduve,

día a día,

sobre la misma palma de tu Mano. 172

La mano en el poema de la trinidad era símbolo del Padre, junto con la casa, manos-casa. También se halla complementada con el símbolo de la casa en otro poema.

Cuando la noche llegue, 
Cuando la noche llegue, recógenos a todos

al calor de tu Casa

para siempre. ${ }^{173}$

De este modo la escalología de Casaldáliga es una escalología de retomo a la casa del Padre, con claras resonancias de su casa familiar patcrna. 174 Pero csta escatología no es únicamente personal, sino que es todo cl pucblo, ahora triturado injustamente, el que verá un día la tierra-sin-males, la tierra nuestra, libertad. Toda la esperanza en mayúscula que impulsaba el itinerario del poeta, contra toda esperanza, se convertirá en realidad:

En la hora esperada de los pobres

Yo ví un coro de ángeles revestidos de came

que tocaban sus flautas, tantanes y laúdes...

y la cúpula

vino, toda, abajo.

$Y$ salió el pescador andando libre.

$Y$ el Esposo y la Esposa se besaron, desnudamente puros.

Y fue cuando la tierra, cayendo de rodillas, cantó el primer Tc Deum ecuménico. ${ }^{175}$

Mientras tanto, afurma el obispo de Sao Félix, refiriéndose a Agustín, el obispo de Hipona:

¡No faltarán los elegidos bárbaros

que doblen el Imperio, hermanos de provincias!

Con rostro palestino y al viento de la Historia,

Dios marcha en caravana con nosotros.

¡Las dos Ciudades irán siendo una!176

En cualquier caso, tanto la ciudad como la casa son las del Padre:

Llegar por fin a tu anhelado Rostro

Y echándome entre tus brazos con todos los llegados.

Dejar toda la vida sobre tu Corazón, como un niño dormido despieno para siempre.

¡Y darte a boca llena el nombre: Padre!177

\subsection{Conclusión}

A través de diversas imágenes y símbolos (manos-casa, llagas-pascua, alasvuelo, Tiberiades, Carmelo, viento...) y de expresiones poéticas preñadas de contenido (el octavo sacramento, versión de Dios en pequeñez humana, trinidad venida a menos, las brasas y las llagas encendidas, profetisa de la liberación, el corazón lleno de nombres...) Casaldáliga nos ofrece un universo tcológico no sólo bello, sino de gran riqueza. Pero hay algo común que une a lodos estos símbolos y es la perspectiva liberadora, la lectura de la fe desde los pobres, desde 
olvidadas, niffos abandonados, mártires anónimos...). La pregunta que el obispo hace al entrevistador Teofilo Cabestrero es pertinente:

El Dios vivo de estos pobres

¿es el nuestro, oh Teofilo? ${ }^{178}$

La experiencia espiritual y teologal del poeta no es únicamente mística ni estética, sino prolética y liberadora, desde los pobres, piedra de escándalo y piedra angular de la Iglesia y del mundo:

Los constructores de la Ciudad

- la Ciudad de Dios, la ciudad del hombre-

habitan siempre en la periferia. ${ }^{179}$

La profecía de Casaldáliga, como la del tesbita Elías, es experiencia de Dios en la historia del pueblo, es subir y bajar del monte Carmelo, es voz de los sin voz. Con razón le escribe Emesto Cardenal:

Profela allí donde se junta el Araguaia y el Xingú

y también poeta

usted es voz de los que tienen esparadrapos en la boca. 180

Por esto su poesía, su profecía, su espiritualidad, su mística es para muchos incómoda y peligrosa, mientras que para los pobres es clara, sencilla, ortodoxa, evangélica. Es teología de frontera.

\section{Epilogo}

Hace algunos años, una facultad teológica europea decidio, por votación de profesores y alumnos, nombrar a Casaldáliga Doctor honoris causa en teologia Pero hubo un veto de las altas instancias académicas (¿locales? ¿vaticanas?) y se adujo que Casaldáliga era poeta, pero no teólogo. Estrecho concepto de teologia el que niega a Casaldáliga la categoria de teologo. Seria mejor haber dicho que es un teólogo de frontera, peligroso, como todos los profetas de la historia. Aludiendo a esta negativa el teólogo Ll. Duch escribio:

Casaldáliga no ha sido reconocido oficialmente como teólogo: para el quizá sea una suente; para la institución hubiera podido significar la posibilidad de reconocer un profeta en su patria. ${ }^{181}$

Gustavo Gutiérrez ha escrito que toda teología auténtica se nutre de una fuerte espiritualidad. ${ }^{182}$ La teología de la liberación es incomprensible $\sin$ las comunidades eclesiales de base, la religiosidad popular de América latina, los mártires, las nuevas figuras de obispos, sacerdotes y religiosos que optan por los pobres, sin Medellín...Los teólogos de la liberación tienen detrás suyo no sollo bibliotecas, sino a todo un pueblo. La liberación es un proceso histórico, no sólo religioso. Esto explica que se pueda hablar de diferentes niveles de teologia de liberación, el profesional (libros, artículos...), el pastoral (documentos pastorales...), y el popular (programas, hojas, círculos biblicos...).183 Pero tal vez se pueda decir algo más. Precisamente por ser un amplio movimiento espiritual e 
pueda decir algo más. Precisamente por ser un amplio movimiento espiritual e histórico, la teología de la liberación tiene también pintores como la escuela de Solentiname o los murales y dibujos de Maximino Cerezo; ensaye estilos nuevos de liturgias, con canciones elaboradas por las comunidades de bese (por ejemplo la canción de la pirámide...); posee poetas como Emesto Cardenal, Pedro Trigo, Pedro Casaldáliga....El ámbito de lo teológico se extiende mucho más que a lo simplemente acadénico.

Teniendo todo esto en cuenta, no se puede negar que Casaldáliga petenece a todo este amplio movimiento teológico y espiritual que llamanos teología de la liberación, con la modalidad propia de una poesía profética, desde los pobres, desde la frontera. Seguramente esto es dificil de entender en otros ambientes teologicos que identifican la toologia exclusivamente con lo profesional y académico. ${ }^{184}$

Ouras muchas casas se hubieran podido decir, y se deberan decir, de la teología poetica de Pedro Casaldáliga. Es ya audacia haberlo intentado. Pero en estos momentos de "inviemo eclesial," la poesía de Casaldáliga representa para la teología un fuerte viento de libertad:

Para que seamos viento en el Viento, hermanos...

\section{Notas}

99. T. Cebeserero, Diallogo sen Maso Grosso, p. 15.

100. "El mirerio," TE, p. 75.

101. "Selmo de abril en Seo Paulo," TE, p.39

102. Ibidem, pp. $42-43$.

103. "Clerosaro," TE. p.99

104. "Te has de encontrar," TE, p. 116.

105. "Solo llegando a la grum," TE, p. 108.

106. "Mi vide, mi muene," TE, p. 96

107. "Equivocos," TN, p. 89

108. "Bendición de S. Francisco \& Fray Leonardo Boff," TE, p.53; cfr. Mt, p. 37

109. "Al Criseo de in Trinidad de Maximino Cerezo Barredo," TE, p.47

110. No vamos a repetir lodo lo dicho en el eprgrafe" Tiempo de pasión," que deberá cenerse en cuenta pare valorar la cristología del autor.

111. "Aaukrdate de Jesucrisio," TN, p. 67; cfr., "Sefilor Jesúrl" TN, p. 137.

112. "Kenosis," TE, p. 89.

114. "Versión de Dios," TE, p. 24.

115. "Navided tepirape," TN, p. 87.

166. "Si faluen los pestores," TE, P. 112 ofr., "Navided de 1973," TN, p. 146.

117. "Y el Verbo se hizo cluse," FC, p. 11.

118. "La meriare, "FC., p. 16; efr., "Hambre de TT," TE, p. 58.

119. "Jexis de Nazarel" TE, p. 25; cfr., "Podrín ser el Mar de Tiberiades ," TE, p. 92.

120. "El pobre y Tú," TE, p. 111.

121. "Marta de cade dia," FC, p. 47.

122. "Mujer de compo," TN, pp. 24-25.

123. "Comadre de suburbio," TN, pp. 26-27.

124. "Señora de la ciudad, "TN, Pp. 28-29. 
125. "Senta Marfe sin más titulos," TN, p. 73.

126. "Negn," TN, p. 23.

127. "Misa de la tierra-sin-males," p. 54.

128. "Soleded," TN, p.20.

129. "Sefion de la muere," TN, p. 30.

130. "Marfa de nuestr liberación," EP, p. 137.

131. "Sente Marin ain mít títulos," TN. p. 73.

132. "Maria Pentecoutes," FC, p. 63.

133. "Podrie ser el mar de Tiberiades," TE, P. 92.

134. "Pedro, ıme unes?," FC, p. 27.

135. "Salmo entre esperanzedo y melanoslico de un obispo techedo de comunien," MC. p. $\boldsymbol{Z}$.

136. "Bendición de Sen Frncisco a Frny Leanerdo Boff," TE, p. 53.

137. "Deja la curin, Pedro," TE, p. 49.

138. "A Jum Pablo I," FC, p. 76.

139. "Oanvo secramento," FC, p. 64.

140. "Preguntes pare subir y bajar el monte Cermelo," TE, p. 36.

141. "El pan de cade dia," FC, p. 81.

142. "Culio vivo," FC, p. 83.

143. "Al cipres de Irsici," TE, p.30. En Irecici re reste in conferencin episcopal bresilefe.

144. "Numer te canoes del Reino," FC, p. 12.

145. "Somos an úlims insuncin," TE, p. 82.

146. "A contromeno," TE, p. 109.

147. "En Grodo," TE, p. 14.

148. "Los dos sefiore," FC, p. 79.

149. "Pobreza evengtlian," TN, p. 51.

150. "Bendición de Sen Frencieso a Fray Lecourdo Boff," TE, p. 52

151. "¿ $\mathrm{Y}$ que le dirfa un afo despuer, mi compedre S. Francisco a Frny Leonerdo Boff," TE, p. S4.

152. "Coniar allibe," FC, p. 30; efr." "Aviso previo a unou muchachou que spine a cer cellibes." TE, p. 28.

153. "Preguntus para subir y bajar el mante Comelo," TE, pp. 35-36.

154. "Retiro espirioul on el cerro de Sante Tereainha," TE. p. 51; off., "No me imporn que me expulıen," FC, p. 34.

155. "Marie Penteconten," FC, p. 63.

156. "Bendición de Son Francisco a Frny Leconerdo Boff," TE, p. 53.

157. "A Jumn Pablo I, , FC. p. 76.

158. "Pueblo," RF, p. 49.

159. "Al Cristo de le Trinided de Maximino Cerezo Barredo," TE, p. 47.

160. FC, pp. 7-8.

161. "Reiro espisiual en el cerro de Semu Terezinha," TE, PP. 50-51.

162. "Sonetillo, yo," TE, p. 16.

163. "Romancillo de la muerte," MC, pp. 13-14.

164. "Ella," FC, p. 57.

165. "Le horn de la verded," Fc. p. 88.

166. "Mi vide, mi muerte," TE, p. 96.

167. "Preacenciss," TN, p. 36.

168. "Meneaje a Selvedor Espriu," TN, Pp. 142-143.

169. "Ella vendra," TE p. 21.

170. "Hablemos del tiempo, hemeno," TE, p. 104.

171. "Olvido/Memoria," TE, p. 83.

172. "El corazkn lleno de nombre," TE, p. 100.

173. "La palmd de $u$ Mano," FC, p. 90.

174. "Juicio funal," FC, p. 89.

175. En su obre postica en calalon, hay une poesis tiwlade "Retom pairl," dende desarrolle eate 
miseno simbolo Deno de resonancias de su tiem y su familia, Encara avui respiro en catalán. pp. 127-131.

176. "Apocalipsis, " FC. p. 86; cfr., todo el aparado "Esperanza contra toda esperanza"

177. De Hipone had Seo Ftlix," TE, p. 61.

178. "Llegar por fin a us anhelado Rostro," TE, p. 95.

179. T. Cebestrero, Didlogas en el Maso Grasso, p. 15.

180. "Los consuructores," FC, p. 43

181. "Ep(stoln a Monseflor Cesaldfilige," TN, p. VII.

182. LI. Duch, La experiencia religiosa en el contexto de la cultwa contemportinea, Barcelona, 1979, p. 11. Ense libro enu dedicedo a Casaldáliga.

183. G. Gutierrez, Beber en su propio pozo, Salamanca, 1984, pp. 50-53.

184. L Boff, C. Boff, Como hacer leología de la liberación, Bogots, 1985, pp. 21-22. 